- More under $16 \mathrm{~s}$ are sexually active than previously reported, especially those who are low achievers academically

- Under $16 \mathrm{~s}$ have better awareness of the existence of emergency contraception than previously reported

- Despite good awareness of emergency contraception, teenagers have poor knowledge of specific details-particularly time limits and safety

- One third of sexually active girls aged under 16 have used emergency contraception

- Health education initiatives should concentrate on the practicalities of emergency contraception and target teenagers at particular risk
The questionnaire used in the survey may be obtained by writing direct to AG. We thank the schools, teachers, and especially the pupils who took part as well as Lothian Education for its cooperation. We also thank Fiona Sutter for help with computing, Ian Young (Health Education Board for Scotland) for help and advice, and Peter Brocklehurst (National Perinatal Epidemiology Unit, Oxford) for statistical advice.

Funding: None.

Conflict of interest: None.

Secretary of State for Health. The health of the nation: a strategy for health in England. London: HMSO, 1992.

2 Johnson AM, Wadsworth J, Wellings K, Field J. Sexual attirudes and lifestyles. Oxford: Blackwell Science, 1994.

3 Mellanby A, Phelps F, Tripp JH. Teenagers, sex, and risk taking. $B M$ 1993;307:25.

4 Burton R, Savage W, Reader F. The "morning after pill" is the wrong name for it: women's knowledge of postcoital contraception in Tower Hamlets. British Yournal of Family Planning 1990;15:119-21.

secondary contracepBromham DR, Cartmill RSV. Knowledge and use of secondary contraception among patients requesting termination of pregnancy. $B M$ 1993;306:556-7.

lowest pregnancy rates in areas where family plannin clinics were available in addition to services provided in primary care, and this was especially noticeable in the under $16 \mathrm{~s} .^{13}$

Health education initiatives should be directed towards teenagers who are at high risk of becoming sexually active at a young age and less well informed about emergency contraception. Smith suggested that areas of socioeconomic deprivation should be targeted. ${ }^{14}$ Our study suggests that schools with lower academic attainment should also be included in this type of initiative.

\section{Conclusion}

Emergency contraception has the potential to prevent unwanted pregnancies. ${ }^{15}$ Most teenagers in Lothian are aware that emergency contraception exists. Use, however, will increase only when potential users believe it to be safe and know where to obtain it and when to use it. These aspects need to be tackled now. Schools and the media could be used more effectively to maximise the potential benefits of emergency contraception in the under $16 \mathrm{~s}$.
6 Duncan G, Harper C, Ashwell E, Mant D, Buchan H, Jones L. Termination of pregnancy: lessons for prevention. British fournal of Family Planning 1990;15:112-7.

7 Audit Unit, Her Majesty's Inspectors of Schools. Examination results in Scottish schools 1993-95. Information for parents. Edinburgh: Scottish Office, 1995.

8 George J, Turner J, Cooke E, Hennessey E, Savage W, Julian P, et al. 1994;44:451-4.

9 Pearson VAH, Owen MR, Phillips DR, Pereiera Gray DJ, Marshall MN Pregnant teenagers' knowledge of use of emergency contraception. BMg 1995;310:1644.

10 Burton R, Savage W. Knowledge of use of postcoital contraception: a survey among health professionals in Tower Hamlets. Br $f$ Gen Pract vey among healt

11 Mellanby AR, Phelps FR, Crichton NJ, Tripp JH. School sex education: an experimental programme with educational and medical benefit. $B M$ 1995;311:414-7.

12 Department of Health. General household survey. London: HMSO, 1992.

13 Allaby $M$. Contraceptive services for teenagers: do we need family planning clinics? $B M Y$ 1995;310:1641-3.

14 Smith $T$. Influence of socioeconomic factors on attaining targets for reduc-

15 Trussell J, Stewart F, Guest F, Hatcher RA. Emergency contraceptive pills: a simple proposal to reduce unintended pregnancies. Fam Plann Perspect 1992;24:269-73. Women's knowledge of emergency contraception. $\mathrm{Br} f \mathrm{Gen}$ Pract ing teenage pregnancies. $B M F$ 1993;306:1232-5.

(Accepted 11 April 1996)
Division of Human Nutrition, Commonwealth Scientific Industrial Research Organisation, Adelaide, SA 5000, Australia

Shilu Tong, doctoral student Peter Baghurst, principal research scientist

Jane Mudge, doctoral student

Department of

Epidemiology and

Population Sciences, London School of Hygiene and Tropical Medicine, London WC1E 7HT Anthony McMichael, professor of epidemiology

Evaluation Unit, Women's and Children's Hospital, Adelaide, SA 5000,

Australia

Michael Sawyer, director

Correspondence to: Dr S Tong, Department of Health Services

Management and Public

Health, University of

New England, Armidale,

NSW 2351, Australia.

$B M F$ 1996;312:1569-75

\title{
Lifetime exposure to environmental lead and children's intelligence at 11-13 years: the Port Pirie cohort study
}

\author{
Shilu Tong, Peter Baghurst, Anthony McMichael, Michael Sawyer, Jane Mudge
}

\section{Abstract}

Objective-To examine the association between environmental exposure to lead and children's intelligence at age 11-13 years, and to assess the implications of exposure in the first seven years of life for later childhood development.

Design-Prospective cohort study.

Subjects-375 children born in or around the lead smelting town of Port Pirie, Australia, between 1979 and 1982.

Main outcome measure-Children's intelligence quotient (IQ) measured at 11-13 years of age.

Results-IQ was inversely associated with both antenatal and postnatal blood lead concentrations. Verbal, performance, and full scale IQ were inversely related to blood lead concentration with no apparent threshold. Multivariate analyses indicated that after adjustment for a wide range of confounders, the postnatal blood lead concentrations (particularly within the age range 15 months to 7 years) exhibited inverse associations with $I Q$. Strong associations with IQ were observed for lifetime average blood lead concentrations at various ages. The expected mean full scale IQ declined by 3.0 points $(95 \%$ confidence interval 0.07 to 5.93$)$ for an increase in lifetime average blood lead concentration from 0.48 to $0.96 \mu \mathrm{mol} / 1$ (10 to $20 \mu \mathrm{g} / \mathrm{dl}$ ).

Conclusions-Exposure to environmental lead during the first seven years of life is associated with cognitive deficits that seem to persist into later childhood.

\section{Introduction}

Many studies have reported inverse associations between low level lead exposure and neuropsychological development, particularly cognitive function. ${ }^{1-17}$ The accumulation of this evidence has prompted public health authorities in several countries progressively to lower the blood lead concentrations at which environmental intervention and medical evaluation is warranted. ${ }^{18}{ }^{19}$ Since both Australian and American data indicate that the high childhood blood lead concentrations of 13-15 years ago are definitely decreasing, ${ }^{19}{ }^{20}$ a contemporary question of great interest is whether the effects of early exposure to lead still persist into later life when lead exposure is generally much lower.

The Port Pirie cohort study started in 1979. Within this cohort, the geometric mean blood lead concentration in the children increased from $8.3 \mu \mathrm{g} / \mathrm{dl}(0.40$ $\mathrm{mmol} / \mathrm{l}$ ) at birth (umbilical cord blood) to $21.2 \mu \mathrm{g} / \mathrm{dl}$ $(1.02 \mathrm{mmol} / \mathrm{l})$ at age 2 years, and had decreased to 11.6 
$\mu \mathrm{g} / \mathrm{dl}(0.56 \mathrm{mmol} / \mathrm{l})$ by the age of 7 years. ${ }^{11}$ In previous studies, we reported that after adjustment for a wide range of confounding factors, postnatal blood lead concentrations in this cohort of children were inversely associated with scores obtained with the Bayley scales of infant development at age 2, the McCarthy scales of children's abilities at age 4, and the Wechsler intelligence scale for children at age $7 .^{9-11}$ This paper reports the findings obtained when the children's intelligence quotients (IQ) were reassessed at age 11-13 years.

\section{Methods \\ SUBJECTS}

The initial sample comprised 723 singleton children born in and around the city of Port Pirie (site of one of the largest lead smelting facilities in the southern hemisphere) during a three year period from 1979 to 1982 . These infants represented an estimated $90 \%$ of singleton live births in the community during this period.

Blood samples for measurement of lead concentrations were taken from pregnant women at specific stages of pregnancy and from each child at delivery (from the umbilical cord) and at ages 6,15 , and 24 months, and annually thereafter up to age 7 years. Measurements of developmental status of the children were made at ages 2,4 , and 7 years; full details are provided in the reports of the results..$^{9-11}$

The base population for the present study comprised the 494 children who were assessed at age 7 years (fig 1). Of the 22 children who were considered ineligible, 21 were excluded because they had missed more than two blood lead measurements during their first seven years, and one was excluded on the basis of having suffered a head injury.

Of the 472 eligible children, $55(11.7 \%)$ could not be contacted ( 34 had moved and 21 could not be reached despite intensive efforts to contact them at home); 37 $(7.8 \%)$ refused to participate; and a further five $(1.0 \%)$ were contacted but were living too far away for the assessor to be sent. The number of children finally assessed was $375(79.4 \%)$. The median age of the children on the day of testing was 12.0 (SD 0.7 ) years (25th and 75 th centiles 11.4 and 12.5 years).

The 375 children who were evaluated at age 11-13 years did not differ significantly from the 119 children lost to follow up on most characteristics, including demographic, socioenvironmental, and biomedical factors. However, parents of the children remaining in the cohort at age 11-13 years had slightly higher occupational prestige than those lost to follow up (table 1).

The possibility of bias in the estimated lead-IQ relation due to a selective loss to follow up was evaluated by comparing the estimated Pearson correlation coefficient of lifetime average blood lead concentration at age 7 with IQ (also at age 7) in the children lost to follow up

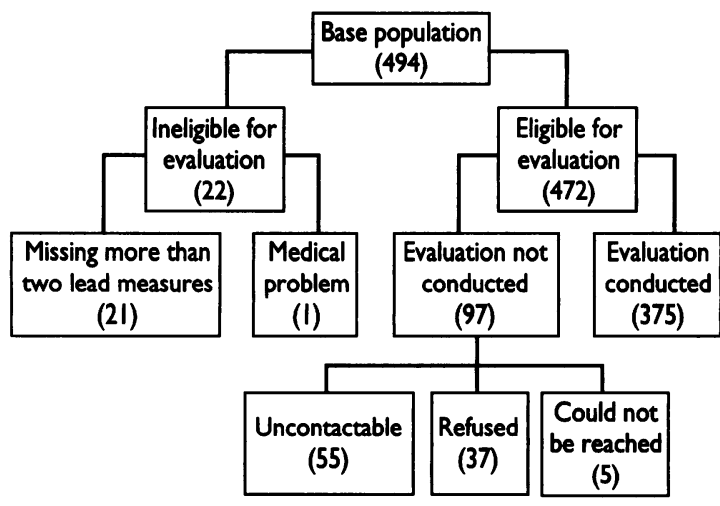

Fig 1-Sources of attrition of Port Pirie cohort study population between ages 7 and $11-13$ years
Table 1-Characteristics of children remaining in the cohort and lost to follow-up at age 11-13 years. Values are percentages (numbers) of children or mean (SD) values

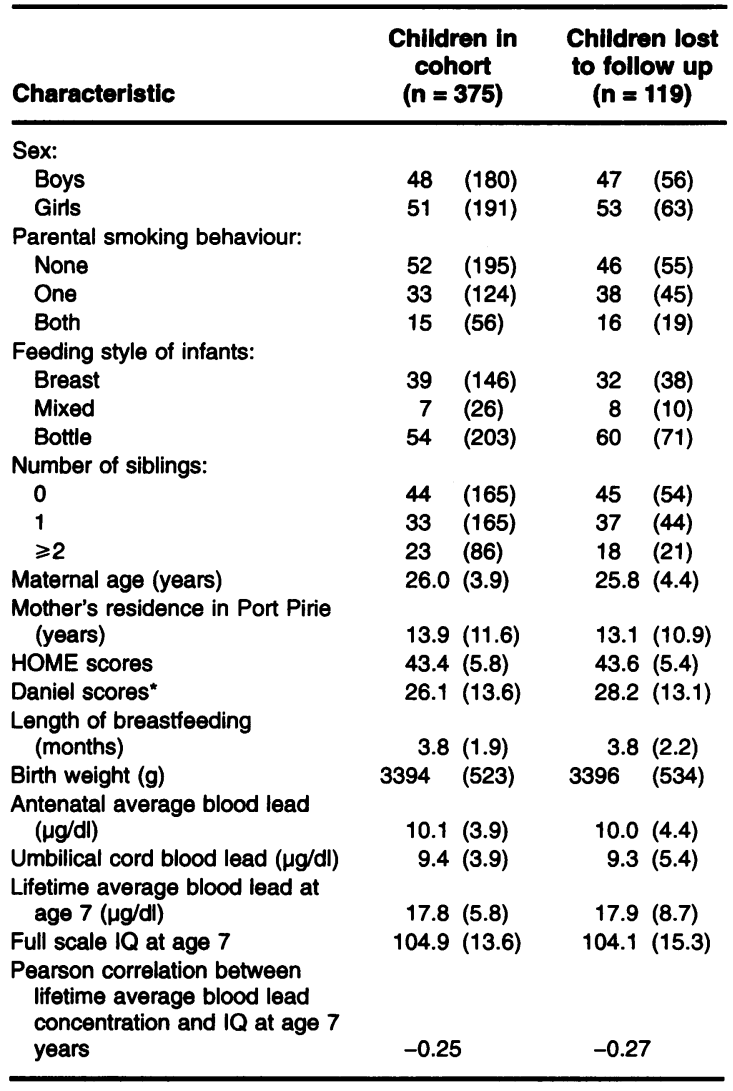

" Higher Daniel scores mean lower socioeconomic status.

in those still in the cohort at age 11-13. The estimates were almost identical: -0.27 for those lost to follow up and -0.25 for the children remaining in the cohort.

\section{DEVELOPMENTAL ASSESSMENT}

The revised version of the Wechsler intelligence scale for children was used to assess the cognitive abilities of each child at age 11-13 years. ${ }^{21}$ This scale is a test of general intelligence developed for use with children aged 6-16 years. In addition to providing a rating of a child's overall intelligence, the test includes a verbal IQ, which provides a rating of verbal comprehension, and a performance IQ, which provides a rating of a child's perceptual organisation. There are 12 subtests within the scale. Scores for the information, similarities, arithmetic, vocabulary, and comprehension subtests contribute to the verbal IQ performance $I Q$ is assessed from the scores obtained with the picture completion, picture arrangement, block design, object assembly, and coding subtests. Two further subtests, digit span and mazes, are supplementary and provide additional qualitative and quantitative information about a child's intellectual abilities. ${ }^{21}$

To reduce measurement bias, quality control procedures were undertaken throughout the study. Firstly, the subjects were evaluated by the same trained examiner, who had not participated in earlier phases of the cohort study and was unaware of any aspect of the children's developmental histories and exposure to lead. Secondly, all assessments were conducted according to a standardised protocol. Finally, children with different exposure status in early life were assessed in an intermixed order.

Mean IQ scores showed a slight downward drift (not statistically significant) toward the end of the study, which suggests that intraexaminer variability over time was unlikely to have been a problem in this study. 
MEASUREMENTS OF LEAD EXPOSURE

Venous blood samples were obtained at age 11-13 years, and estimations of blood lead concentrations were performed in the department of chemical pathology at the Adelaide Women's and Children's Hospital by electrothermal atomisation atomic absorption spectrometry. ${ }^{22}$ The blood lead assay was subject to internal and external quality control procedures, with consistently satisfactory results. ${ }^{10} 11$ A certified, commercially prepared product was used to monitor intrabatch accuracy and to ensure uniformity between batches (the coefficient of variation for measurements was $\leqslant 5.7 \%$ ). External quality control, entailing assays of regularly supplied samples, was ensured by participation in the international programmes run by the health department of Pennsylvania, USA, and the Wolfson Research Laboratory (Birmingham, UK). Estimates were standardised to a packed cell volume of $50 \%$ for cord blood and $35 \%$ for all other samples.

MEASUREMENT OF COVARIATES

An important methodological consideration is the selection and measurement of covariates that influence childhood intelligence and might be related to lead exposure, and which might therefore confound any true relation between lead exposure and IQ. The covariates considered in this study included parents' occupational prestige, which was assessed using the Daniel scale of prestige of occupations in Australia (lower scores equate to more prestigious jobs, which are generally associated with higher socioeconomic status) ${ }^{23}$; the child's family functioning, which was measured using the general functioning scale of the family assessment device ${ }^{24}$; mother's psychopathological status, which was evaluated with the general health questionnaire ${ }^{25}$; the caregiving environment, which was assessed with the home observation for measurement of the environment inventory $^{26}$; and maternal intelligence, which was estimated using the Wechsler adult intelligence scale. ${ }^{27}$ Other factors that were measured included the child's iron status, sex, age at testing, and school grade; marital status of the parents; parental smoking habits and parents' years of secondary education; family size; life events; length of mother's residence in Port Pirie; assessment site; maternal age at delivery; birth weight; birth rank; feeding method during infancy (breast, formula, or both); duration of breastfeeding, whether any medication was used in the two weeks before testing; and prolonged absences from school for any single school term during the past five years.

\section{STATISTICAL ANALYSIS}

All reported mean blood lead values are geometric because of their approximate log normal distribution. For calculation of lifetime average blood lead concentrations, a plot of blood lead concentrations against age was constructed for each child. A lifetime average blood lead concentration up to a particular age was estimated by dividing the area under this curve by the specified age.

For describing results in tabular form, blood lead was categorised into thirds at each time of blood sampling. In multivariable analyses, the effects of confounding factors were evaluated with multiple regression models. The selection of potential confounders was based on both a priori and empirical considerations. ${ }^{28}{ }^{29}$ Firstly, important antecedents or correlates of IQ were considered as potential confounders (for example, scores on the home observation for measurement of the environment scale and maternal IQ). Secondly, the variables that were associated, independently, with both blood lead and developmental outcomes within this data set were considered as potential confounders. Thirdly, a change in estimate criterion was used to evaluate each
Table 2-Mean lead concentration (mmol/l) in blood samples taken antenatally and throughout childhood

\begin{tabular}{|c|c|c|c|}
\hline Time of sampling & $\begin{array}{c}\text { No of } \\
\text { children* }\end{array}$ & $\begin{array}{c}\text { Geometric } \\
\text { mean } \\
\text { (geometric } \\
\text { SD) }\end{array}$ & Range \\
\hline Antenatal & 367 & $0.46(0.06)$ & $0.18-1.60$ \\
\hline Cord blood & 328 & $0.41(0.08)$ & $0.04-1.77$ \\
\hline 6 Months & 367 & $0.70(0.07)$ & $0.11-1.78$ \\
\hline 15 Months & 367 & $1.01(0.07)$ & $0.25-2.50$ \\
\hline 24 Months & 372 & $1.03(0.06)$ & $0.42-2.51$ \\
\hline 3 Years & 372 & $0.93(0.06)$ & $0.31-3.00$ \\
\hline 4 Years & 369 & $0.70(0.07)$ & $0.27-1.96$ \\
\hline 5 Years & 368 & $0.69(0.07)$ & $0.23-1.97$ \\
\hline 6 Years & 356 & $0.61(0.07)$ & $0.23-1.65$ \\
\hline 7 Years & 360 & $0.56(0.07)$ & $0.10-1.82$ \\
\hline 11-13 Years & 326 & $0.38(0.08)$ & $0.03-1.49$ \\
\hline Lifetime average & 326 & $0.68(0.06)$ & $0.24-1.54$ \\
\hline
\end{tabular}

*375 Children were followed through to age 11-13.

potential confounder: if the adjusted estimated regression coefficient of the blood lead term differed from the unadjusted estimate by more than $10 \%$, that covariate was included in the final regression model. Finally, the combined effect of potential confounders was assessed by the change in magnitude of the regression coefficients of the lead term after all the potential confounding factors had been adjusted for. The covariates used in the multiple regression models comprised sex, age, school grade, parents' occupational prestige, home observation for measurement of the environment scores, maternal IQ, family functioning scores, parental smoking habits, marital status, parents' level of education, maternal age at delivery, birth weight, birth rank, feeding method during infancy, duration of breastfeeding, family size, life events, and prolonged absences from school for any single school term during the past five years.

\section{Results}

EXPOSURE MEASURES

Table 2 shows the variation of geometric mean blood lead concentrations with age. A sharp increase in blood lead concentration occurred during the first two years of life and was followed by a gradual decline, with the mean concentration at 11-13 years being slightly lower than the level recorded at birth.

\section{OUTCOME MEASURES}

The mean scores for the 12 subscales of the Wechsler intelligence scale for children ranged from 9.2 to 11.3 , and the mean scores for verbal, performance, and full scale IQ were 97.6 (95\% confidence interval 96.6 to $98.7), 103.0$ (101.6 to 104.4 ), and 100 (98.8 to 101.2), respectively (table 3 ).

\section{AGE SPECIFIC BLOOD LEAD CONCENTRATION AND} CHILDRENS' IQ

There was a consistent inverse relation between blood lead concentration and scores for all the IQ scales, unadjusted for covariates (table 4). IQ was significantly associated with blood lead concentrations at all ages except at birth. Decreases in mean IQ scores between the top and bottom thirds of exposure varied from 1.5 points for performance IQ with cord blood lead concentration to 9.1 points for full scale IQ with lifetime average blood lead concentration at age 11-13 years.

The magnitude of the deficit in IQ with increased blood lead was similar for the verbal and performance scales. There was an inverse and statistically significant association between children's IQ and blood lead concentrations measured at most ages, although the 
Table 3-Mean (SD) scores for the WISC-R subscales and IQ scales in 375 children at age 11-13 years

\begin{tabular}{lcc}
\hline Item & Mean (SD) & Range \\
\hline Full scale IQ & $100.0(12.3)$ & $54-145$ \\
Verbal IQ: & $97.6(10.8)$ & $57-139$ \\
Information & $9.9(2.0)$ & $1-17$ \\
Similarities & $9.8(2.4)$ & $1-17$ \\
Arithmetic & $10.0(2.6)$ & $2-18$ \\
Vocabulary & $9.4(2.2)$ & $2-17$ \\
Comprehension & $9.2(2.1)$ & $2-17$ \\
(Digit span) & $9.3(2.9)$ & $2-19$ \\
Performance IQ: & $103.0(14.1)$ & $54-145$ \\
Picture completion & $10.2(2.4)$ & $4-19$ \\
Picture arrangement & $10.1(2.7)$ & $1-18$ \\
Block design & $11.3(3.3)$ & $1-19$ \\
Object sssembly & $11.2(3.1)$ & $3-19$ \\
Coding & $9.6(2.9)$ & $1-18$ \\
(Mazes) & $10.7(2.8)$ & $1-18$ \\
\hline
\end{tabular}

Table 4-Mean IQ scores by third of blood lead concentration (number of children in each third)*

\begin{tabular}{|c|c|c|c|c|c|c|c|c|}
\hline \multirow[b]{2}{*}{ Blood lead third } & \multicolumn{7}{|c|}{ Time of blood sampling } & \multirow[b]{2}{*}{$\begin{array}{l}\text { Lifetime } \\
\text { average }\end{array}$} \\
\hline & Antenatal & $\begin{array}{l}\text { Cord } \\
\text { blood }\end{array}$ & $\begin{array}{c}15 \\
\text { Months }\end{array}$ & $\stackrel{3}{\text { Years }}$ & $\begin{array}{c}5 \\
\text { Years }\end{array}$ & $\begin{array}{c}7 \\
\text { Years }\end{array}$ & $\begin{array}{l}11-13 \\
\text { Years }\end{array}$ & \\
\hline \multicolumn{9}{|c|}{ Mean blood lead concentration (mmol/l): } \\
\hline Low & $\begin{array}{c}0.33 \\
(n=122)\end{array}$ & $\begin{array}{c}0.25 \\
(n=109)\end{array}$ & $\begin{array}{c}0.63 \\
(n=122)\end{array}$ & $\begin{array}{c}0.62 \\
(n=124)\end{array}$ & $\begin{array}{c}0.43 \\
(n=123)\end{array}$ & $\begin{array}{c}0.35 \\
(n=120)\end{array}$ & $\begin{array}{c}0.25 \\
(n=109)\end{array}$ & $\begin{array}{c}0.47 \\
(n=109)\end{array}$ \\
\hline Medium & $\begin{array}{c}0.47 \\
(n=123)\end{array}$ & $\begin{array}{c}0.42 \\
(n=110)\end{array}$ & $\begin{array}{c}1.05 \\
(n=123)\end{array}$ & $\begin{array}{c}0.96 \\
(n=124)\end{array}$ & $\begin{array}{c}0.72 \\
(n=122)\end{array}$ & $\begin{array}{c}0.57 \\
(n=120)\end{array}$ & $\begin{array}{c}0.43 \\
(n=108)\end{array}$ & $\begin{array}{c}0.71 \\
(n=108)\end{array}$ \\
\hline High & $\begin{array}{c}0.64 \\
(n=122)\end{array}$ & $\begin{array}{c}0.66 \\
(n=109)\end{array}$ & $\begin{array}{c}1.58 \\
(n=122)\end{array}$ & $\begin{array}{c}1.37 \\
(n=124)\end{array}$ & $\begin{array}{c}1.08 \\
(n=123)\end{array}$ & $\begin{array}{c}0.89 \\
(n=120)\end{array}$ & $\begin{array}{c}0.70 \\
(n=109)\end{array}$ & $\begin{array}{c}1.01 \\
(n=109)\end{array}$ \\
\hline \multicolumn{9}{|l|}{ Full scale IQ: } \\
\hline Low & 103.1 & 101.8 & 103.4 & 104.4 & 104.3 & 104.0 & 103.0 & 104.1 \\
\hline Medium & 100.2 & 99.6 & 100.9 & 99.8 & 99.8 & 100.4 & 100.2 & 101.3 \\
\hline High & 97.5 & 99.3 & 96.0 & 96.2 & 96.1 & 95.8 & 97.3 & 95.0 \\
\hline \multicolumn{9}{|l|}{ Verbal IQ: } \\
\hline Low & 100.1 & 99.1 & 100.5 & 101.5 & 101.8 & 101.2 & 100.4 & 101.4 \\
\hline Medium & 97.6 & 98.4 & 98.7 & 97.5 & 98.0 & 98.3 & 97.8 & 98.7 \\
\hline High & 95.8 & 96.3 & 93.9 & 94.4 & 93.1 & 93.5 & 95.4 & 93.2 \\
\hline \multicolumn{9}{|l|}{ Performance IQ: } \\
\hline Low & 106.0 & 104.7 & 106.4 & 107.2 & 106.7 & 106.9 & 106.0 & 106.9 \\
\hline Medium & 103.5 & 101.2 & 103.6 & 102.8 & 102.2 & 102.7 & 103.1 & 103.9 \\
\hline High & 100.2 & 103.2 & 99.4 & 99.4 & 100.4 & 99.4 & 100.3 & 98.4 \\
\hline
\end{tabular}

"Differences between thirds of blood lead and IQs were statistically significant $(P<0.01)$ in every instance except for the variation of IQs with cord blood lead concentrations $(P \leqslant 0.25)$.

relatively larger IQ deficits were associated with blood lead concentrations measured at earlier ages and with lifetime average blood lead concentration. The proportion of the variance of full scale IQ that could be attributed to blood lead concentrations at different ages, without consideration of the potential confounders, varied from $0.8 \%$ (cord sample) to $10.1 \%$ (lifetime average value).

Figure 2 (top) shows the unadjusted relation between children's mean IQ and lifetime average blood lead concentration. Generally, for each IQ scale, there was an inverse gradient across the whole range of blood lead concentration without an apparent threshold. The trend was similar for each IQ scale. Figure 2 (bottom) shows the variation of mean residual IQ (observed minus expected values) after IQ was regressed on the potential confounders used in this study. A dose related decrease in IQ with increasing blood lead concentration was still evident, although the range in residual IQ was substantially less than that seen with unadjusted IQ data.

REGRESSION ANALYSES OF IQ SCALE AND SUBSCALE SCORES

In simple regression analyses, all measures of blood lead except those for the cord sample were significantly inversely associated with IQ. The magnitude of regression coefficients of blood lead concentration for verbal IQ was similar to that for performance IQ (table 5).
In multiple regression analyses, the inverse associations between blood lead concentration and IQ were attenuated after the effects of potential confounders were adjusted for. In particular, the associations of children's IQ with maternal and cord blood lead concentrations became insignificant. The covariates contributing most to this attenuating effect were those identified as being most closely related to both blood lead and children's IQ - that is, socioeconomic status, scores on the home observation for measurement of the environment scales, and maternal intelligence. However, the inverse associations between various measures of blood lead concentrations over the age range 15 months to 7 years and IQ (mainly verbal and full scale IQ) remained statistically significant or marginally significant after potential confounders had been taken into account. The stronger associations were found between lifetime average blood lead concentrations at various ages and IQ. It is estimated that the mean score for full scale IQ declined by 3.0 points $(0.07$ to 5.93$)$ for a doubling in lifetime average blood lead concentration at age 11-13 years within the range studied.

Multiple regression analyses of the Wechsler subscale scores show that most of the mean subscale scores were inversely associated with the lifetime average blood lead concentration at age 11-13 years (table 6). However, the strength of these associations varied considerably. The associations of lifetime average blood lead concentration with the information, arithmetic, block design, and maze subscales were stronger than those for any other subscales.

PERSISTENCE OF ASSOCIATION BETWEEN BLOOD LEAD CONCENTRATION AND CHILDREN'S DEVELOPMENT

Data on the histories of lead exposure and cognitive development in the children by thirds of lifetime average
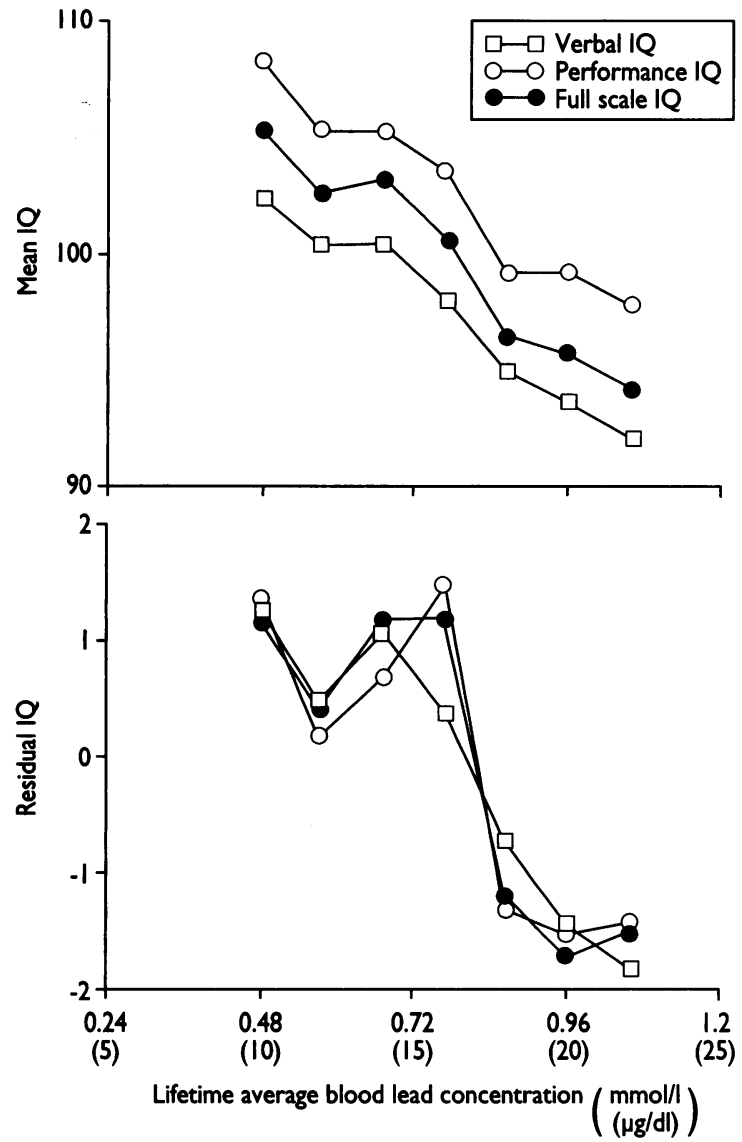

Fig 2- Relation of lifetime average blood lead concentration and children's IQ: (top) mean IQ; (bottom) mean residual IQ 
Table 5-Estimated regression coefficients (SE) in $1 Q$ points per unit of log blood lead concentration from simple and multiple regression analyses

\begin{tabular}{|c|c|c|c|c|c|c|}
\hline \multirow[b]{2}{*}{ Time of blood sampling } & \multicolumn{3}{|c|}{ Unadjusted } & \multicolumn{3}{|c|}{ Adjusted $\boldsymbol{t}$} \\
\hline & Verbal IQ & $\begin{array}{l}\text { Performance } \\
\text { IQ }\end{array}$ & $\begin{array}{c}\text { Full scale } \\
\text { IQ }\end{array}$ & Verbal IQ & $\begin{array}{l}\text { Performance } \\
\text { IQ }\end{array}$ & $\begin{array}{c}\text { Full scale } \\
\text { IQ }\end{array}$ \\
\hline Cord blood & $\begin{array}{l}-2.9(1.3) \\
(P=0.03)\end{array}$ & $\begin{array}{l}-1.8(1.6) \\
(P=0.25)\end{array}$ & $\begin{array}{l}-2.7(1.4) \\
(P=0.06)\end{array}$ & $\begin{array}{l}1.0(1.3) \\
(P=0.43)\end{array}$ & $\begin{array}{l}1.2(1.8) \\
(P=0.48)\end{array}$ & $\begin{array}{l}1.2(1.5) \\
(P=0.41)\end{array}$ \\
\hline 15 Months & $-6.4(1.3)$ & $-5.2(1.7)$ & $-6.2(1.5)$ & $\begin{array}{c}-2.9(1.3) \\
(P=0.03)\end{array}$ & $\begin{array}{c}-0.6(1.9) \\
(P=0.76)\end{array}$ & $\begin{array}{c}-1.8(1.6) \\
(P=0.24)\end{array}$ \\
\hline 3 Years & $-8.5(1.5)$ & $-9.4(2.0)$ & $-9.8(1.7)$ & $\begin{array}{c}-2.6(1.6) \\
(P=0.11)\end{array}$ & $\begin{array}{c}-4.2(2.3) \\
(P=0.07)\end{array}$ & $\begin{array}{c}-3.8(1.9) \\
(P=0.05)\end{array}$ \\
\hline 5 Years & $-8.4(1.3)$ & $-7.2(1.7)$ & $-8.9(1.5)$ & $\begin{array}{c}-3.7(1.4) \\
(P=0.01)\end{array}$ & $\begin{array}{c}-3.7(1.9) \\
(P=0.06)\end{array}$ & $\begin{array}{c}-4.0(1.6) \\
(P=0.02)\end{array}$ \\
\hline 7 Years & $-7.9(1.3)$ & $-8.6(1.7)$ & $-8.9(1.5)$ & $\begin{array}{c}-2.8(1.4) \\
(P=0.05)\end{array}$ & $\begin{array}{c}-3.8(2.0) \\
(P=0.06)\end{array}$ & $\begin{array}{c}-3.4(1.7) \\
(P=0.04)\end{array}$ \\
\hline $11-13$ Years & $-5.7(1.3)$ & $-6.2(1.7)$ & $-6.5(1.4)$ & $\begin{array}{c}-2.4(1.3) \\
(P=0.06)\end{array}$ & $\begin{array}{c}-2.0(1.8) \\
(P=0.12)\end{array}$ & $\begin{array}{c}-3.1(1.4) \\
(P=0.04)\end{array}$ \\
\hline Lifetime average to age 3 & $-9.3(1.8)$ & $-7.8(2.4)$ & $-9.5(2.1)$ & $\begin{array}{c}-4.6(1.9) \\
(P=0.03)\end{array}$ & $\begin{array}{c}-3.2(2.7) \\
(P=0.23)\end{array}$ & $\begin{array}{c}-4.3(2.2) \\
(P=0.06)\end{array}$ \\
\hline Lifetime average to age 5 & $-9.8(1.9)$ & $-8.6(2.4)$ & $-10.1(2.1)$ & $\begin{array}{c}-5.0(2.0) \\
(P=0.02)\end{array}$ & $\begin{array}{c}-4.4(2.8) \\
(P=0.10)\end{array}$ & $\begin{array}{c}-5.1(2.3) \\
(P=0.03)\end{array}$ \\
\hline Lifetime average to age 7 & $-9.6(1.9)$ & $-8.7(2.5)$ & $-10.0(2.2)$ & $\begin{array}{c}-4.3(2.1) \\
(P=0.03)\end{array}$ & $\begin{array}{c}-4.3(2.9) \\
(P=0.14)\end{array}$ & $\begin{array}{c}-4.6(2.4) \\
(P=0.06)\end{array}$ \\
\hline Lifetime average to age $11-13$ & $-10.8(1.6)$ & $-10.8(2.2)$ & $-11.6(1.9)$ & $\begin{array}{c}-3.9(1.8) \\
(P=0.03)\end{array}$ & $\begin{array}{c}-4.7(2.6) \\
(P=0.07)\end{array}$ & $\begin{array}{c}-4.3(2.1) \ddagger \\
(P=0.04)\end{array}$ \\
\hline
\end{tabular}

*All simple regression coefficients except for cord blood lead concentration were significant $(P<0.001)$; $P$ values shown in parentheses are for multiple regression analyses.

tAdjusted for covariates described in the text.

fAnalyses were based on the unit of natural log blood lead concentration in $\mu \mathrm{g} / \mathrm{dl}$; this means that the expected deficit in full scale IQ associated with a doubling of lifetime average blood lead concentration-for example, from 0.48 to $0.97 \mathrm{mmol} / \mathrm{l}$ (10 to $20 \mu \mathrm{g} / \mathrm{dl}$ ) is $3.0 \mathrm{points:}$ $4.3 \times(\ln [20]-\ln [10])=3.0$.

blood lead concentration up to age 2 years (the age when the children's developmental status was assessed for the first time in this cohort study) indicate that the adjusted differences in developmental scores between the top and bottom thirds of exposure were 4.0 points on the Bayley mental developmental index at age $2 ; 4.8$ points on the McCarthy general cognitive index at age 4 ; and 4.9 and $4.5 \mathrm{IQ}$ points at 7 years and $11-13$ years, respectively, after potential confounders had been taken into account (fig 3).

Table 6—Mean (SD) age adjusted subscale scores and estimated regression coefficients of subscale scores with lifetime average blood lead concentration

\begin{tabular}{|c|c|c|c|c|c|}
\hline \multirow[b]{2}{*}{ Subscale } & \multicolumn{3}{|c|}{ Blood lead third } & \multicolumn{2}{|c|}{$\begin{array}{l}\text { Regression } \\
\text { coefficient" }\end{array}$} \\
\hline & Low & Middle & High & $\begin{array}{l}\text { Estimate } \\
\text { (SE) }\end{array}$ & $\underset{\text { value }}{P}$ \\
\hline Information & $\begin{array}{l}10.4 \\
(1.9)\end{array}$ & $\begin{array}{l}10.1 \\
(1.7)\end{array}$ & $\begin{array}{l}9.2 \\
(2.1)\end{array}$ & $-0.90(0.35)$ & 0.01 \\
\hline Similarities & $\begin{array}{l}10.0 \\
(2.3)\end{array}$ & $\begin{array}{l}10.2 \\
(2.3)\end{array}$ & $\begin{array}{c}9.2 \\
(2.6)\end{array}$ & $-0.02(0.46)$ & 0.96 \\
\hline Arithmetic & $\begin{array}{l}10.9 \\
(2.7)\end{array}$ & $\begin{array}{l}10.0 \\
(2.5)\end{array}$ & $\begin{array}{c}9.0 \\
(2.4)\end{array}$ & $-1.62(0.50)$ & $<0.01$ \\
\hline Vocabulary & $\begin{array}{l}10.0 \\
(2.2)\end{array}$ & $\begin{array}{l}9.6 \\
(2.1)\end{array}$ & $\begin{array}{c}8.7 \\
(2.1)\end{array}$ & $-0.51(0.39)$ & 0.19 \\
\hline Comprehension & $\begin{array}{c}9.6 \\
(1.9)\end{array}$ & $\begin{array}{c}9.3 \\
(2.2)\end{array}$ & $\begin{array}{c}8.9 \\
(2.0)\end{array}$ & $0.03(0.40)$ & 0.98 \\
\hline Digit span & $\begin{array}{c}9.9 \\
(3.0)\end{array}$ & $\begin{array}{l}9.3 \\
(2.6)\end{array}$ & $\begin{array}{c}8.7 \\
(3.0)\end{array}$ & $-0.63(0.58)$ & 0.27 \\
\hline $\begin{array}{l}\text { Picture } \\
\text { completion }\end{array}$ & $\begin{array}{l}10.7 \\
(2.4)\end{array}$ & $\begin{array}{l}10.2 \\
(2.4)\end{array}$ & $\begin{array}{c}9.6 \\
(2.4)\end{array}$ & $-0.53(0.47)$ & 0.26 \\
\hline $\begin{array}{l}\text { Picture } \\
\text { arrangement }\end{array}$ & $\begin{array}{l}10.4 \\
(2.7)\end{array}$ & $\begin{array}{l}10.2 \\
(2.6)\end{array}$ & $\begin{array}{c}9.8 \\
(2.6)\end{array}$ & $0.14(0.53)$ & 0.48 \\
\hline Block design & $\begin{array}{l}12.2 \\
(3.0)\end{array}$ & $\begin{array}{l}11.3 \\
(3.2)\end{array}$ & $\begin{array}{l}10.3 \\
(3.4)\end{array}$ & $-1.39(0.62)$ & 0.03 \\
\hline $\begin{array}{l}\text { Object } \\
\text { assembly }\end{array}$ & $\begin{array}{l}11.7 \\
(3.1)\end{array}$ & $\begin{array}{l}11.4 \\
(3.4)\end{array}$ & $\begin{array}{l}10.5 \\
(2.9)\end{array}$ & $-0.75(0.62)$ & 0.22 \\
\hline Coding & $\begin{array}{l}9.9 \\
(2.9)\end{array}$ & $\begin{array}{l}10.0 \\
(2.8)\end{array}$ & $\begin{array}{c}8.9 \\
(3.0)\end{array}$ & $-0.84(0.58)$ & 0.14 \\
\hline Maze & $\begin{array}{l}11.3 \\
(2.8)\end{array}$ & $\begin{array}{l}10.6 \\
(2.9)\end{array}$ & $\begin{array}{l}10.3 \\
(2.7)\end{array}$ & $-1.13(0.51)$ & 0.03 \\
\hline
\end{tabular}

"Coefficients were adjusted for covariates described in the text, as in table 5.

\section{Discussion}

In the latest stage of this prospective study we re-evaluated a group of children aged 11-13 years with lifelong histories of lead exposure and found that the inverse associations between blood lead and cognitive development at ages 2,4 , and 7 years ${ }^{9-11}$ persisted into later childhood. The estimated deficit in full scale IQ at age 11-13 years was 3.0 points for a shift in lifetime average blood lead concentration from 0.48 to 0.96 $\mu \mathrm{mol} / 1$ (10 to $20 \mu \mathrm{g} / \mathrm{dl})$.

This study provides evidence that an association between early exposure to environmental lead and cognitive development persists into later childhood, even though blood lead concentrations in these children had declined substantially since their third year of life. Nevertheless, both the initial effects of environmental lead exposure and the persistence of those effects may

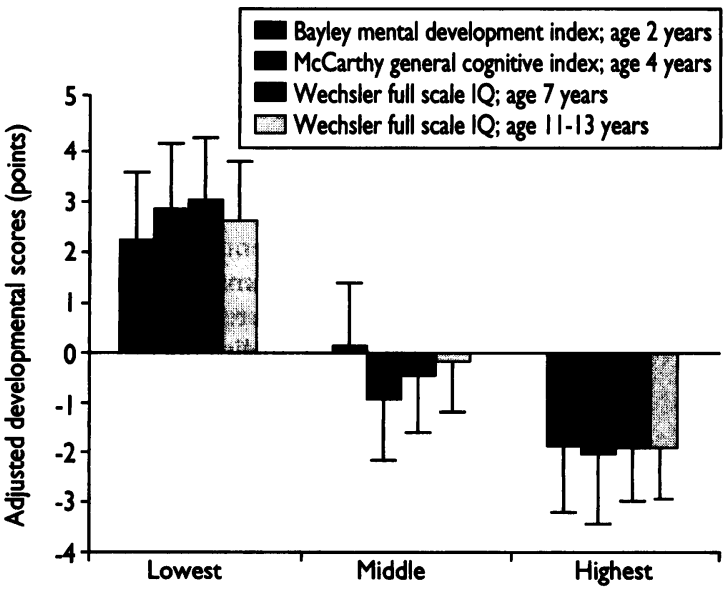

Third of blood lead concentration

Fig 3-Developmental status (adjusted residual scores; bars show SE) at different ages by thirds of lifetime average blood lead concentration at age 2 years. Geometric mean blood lead concentrations for lowest, middle, and highest thirds were $12.5,18.5$, and $25.9 \mu \mathrm{g} / d$ respectively $(0.54,0.79$, and $1.11 \mathrm{mmol} / \mathrm{I})$ ) 
depend not only on the magnitude of exposure but also on the timing and chronicity of exposure and other social and familial factors.

PREVIOUS STUDIES

Only a few studies have looked for a persistent effect of exposure to low levels of lead on cognitive development. A cohort study in Boston found a consistent association between cord blood lead and cognitive development at ages $6,12,18$, and 24 months, but not at later ages. ${ }^{3-5}$ At ages 57 months and 10 years, only the blood lead concentration measured at 2 years of age was found to be associated with the child's development. The exposure related differences in performance at age 10 years were reported to be approximately twice the size of those observed at $\mathbf{5 7}$ months, but the relative magnitude of the association at age 10 years may have been distorted because of differences in characteristics between the continuing participants and those lost to follow up. ${ }^{5}$ Two other studies found that raised concentrations of lead in dentine were associated with deficits in neuropsychological functioning that persisted into later childhood or young adulthood. ${ }^{2}{ }^{30}$ However, since dentine lead concentration was the only measure of exposure in these two studies, the chronology of change in lead exposure status is unknown, making it difficult to judge whether the persistent effects resulted from early exposure or accumulated exposure throughout a lifetime.

\section{REVERSE CAUSATION}

There are several possible explanations for the association observed in this study. Firstly, a rather special potential problem for studies of lead exposure and cognitive development is reverse causation-that is, a lead-IQ association which arises because children who have a lower IQ are allegedly more likely to exhibit behaviours (such as thumb sucking or poorer personal hygiene) that might result in increased lead intake. ${ }^{31}{ }^{32}$ To explore this possibility we examined the temporal relations between lead exposure and children's IQ.

Blood lead measures most strongly related to IQ had all been measured before IQ was assessed (table 5), and none of the developmental scores at earlier ages were significantly associated with the current blood lead measure at age 11-13 years. These analyses-supported by animal research ${ }^{33-35}$ - strengthen the notion that lead exposure influences cognitive development, and not the reverse.

\section{OTHER ALTERNATIVES}

Secondly, it might be argued that the association is an artefact of incomplete or inaccurate assessment of confounding factors. ${ }^{36}$ Though this concern can rarely be dispelled in any observational epidemiological study, persistence of the effects of early exposure to environmental lead has also been found in animal studies, where these confounders are not present. ${ }^{33-35}$

Thirdly, bias due to loss to follow up is unlikely to have an important role in this study because the characteristics of the children who were reassessed at age 11-13 years were similar (with respect to earlier measurements) to those lost to follow up, and the relations between blood lead concentrations and cognitive status at earlier ages were almost identical for these two groups.

\section{THRESHOLD, INTERACTION, AND SENSITIVE INDICES}

In assessing public health risk from exposure to environmental lead, there has been strong interest in the existence, or otherwise, of a level of exposure below which a toxicological effect does not occur. Within the

\section{Key messages}

- There is uncertainty over the existence of any long term effects of exposure to low levels of lead on childhood development

- Few longitudinal data have yet been reported on the time course of the effects of exposure to environmental lead

- Exposure to environmental lead early in life is associated with cognitive deficits that persist into middle childhood

- The duration, intensity, and timing of exposure to lead, as well as other social and familial factors, may influence the nature and degree of reversibility - The formulation of a public health policy for preventing any possible effects of lead exposure should be based on a composite consideration of the child's health and the best use of existing resources

range of blood lead concentration encountered in this study, there was no clear evidence that such a threshold exists.

An important issue in risk assessment of lead exposure is whether the apparent effects of lead exposure are greater in some subgroups, such as children of one sex or a particular socioeconomic background. Stratified analyses indicate that the association between lifetime average blood lead concentration and full scale IQ was stronger for girls (partial regression coefficient $-7.4 ; 95 \%$ confidence interval -13.1 to-1.7) than for boys $(-2.6 ;-8.0$ to 2.9$)$, which is consistent with our findings at ages 4 and 7 years. ${ }^{37}$ The results of further analyses also indicated that the regression coefficients of blood lead were more highly negative for children living in Port Pirie than those living elsewhere, and that children in families with lower socioeconomic status, from home environments of poorer quality, and with mothers of lower intelligence, seemed to be more affected by exposure to lead than those from more advantaged backgrounds-although these differences were not significant after adjustment for confounding factors.

Another important issue that is still being explored is which indices of outcome are the most sensitive to lead. Although global measures of cognitive function, such as full scale IQ, are generally regarded as reliable indices of the effects of lead, specific abilities seem to be more sensitive to the effects of low level exposure to lead than are global measures of cognition. In this study, four subtests of the Wechsler scale were found to be more strongly associated with lifetime average blood lead concentration than the others. Visual-motor coordination, attention, concentration, and memory are considered to be important contributors to these subtests. ${ }^{38} 39$

\section{MECHANISMS FOR THE EFFECTS OF LEAD}

The mechanisms by which lead might exert a toxic effect on cognitive development remain unclear. It has been shown that lead alters release processes for neurotransmitters such as dopamine, norepinephrine, and acetylcholine by interfering with calcium metabolism or synaptic functioning, or both, ${ }^{40-42}$ and that lead exerts effects on the activities of such enzymes as kinase C, calmodulin, tyrosine hydroxylase, and choline acetyltransferase, and also on brain energy metabolism. . $^{4-45}$ However, the direct relevance of these effects to the higher level processes of cognitive functioning assessed during developmental testing remains to be determined. 
Within the context of other studies of the putative effects of lead on cognition it is pertinent to note that the estimates of "effect" produced by the Port Pirie cohort study are a little higher in magnitude than those reported by most, but not all, of the other studies. ${ }^{36}$ The problem of deciding whether these effect estimates are too high because of imperfections in the measurement of other determinants of IQ, or too low because of excessive statistical adjustment for factors which are causally related to exposure, is unlikely to be resolved in the near future. Objective assessment of the currently available epidemiological evidence suggests that any effect of subacute exposure to lead on cognition is likely to be modest. However, since any such effect may be persistent, and since human activities have already greatly increased the overall penetration of lead into the environment, it is entirely appropriate for public health authorities to continue to strive for a reduction in the dispersive uses of this heavy metal.

We are indebted to Mrs Maureen Wauchope for blood sampling and interviews, to $\mathrm{Mr}$ Charles Greeneklee for assessing packed cell volume of blood samples, to Ms Elaine Whitham for blood lead and iron analyses, to Mr Jim Lyster for supervising developmental assessments, and to the families who participated in this study.

Funding: This research was supported by a series of grants from the National Health and Medical Research Council, the Channel 7 Children's Research Foundation, and the University of Adelaide.

Conflict of interest: None.

1 Needleman HL, Gunnoe C, Leviton A, Reed R, Peresie H, Maher C, et al. Deficits in psychologic and classroom performance of children with elevated dentine lead levels. $N$ Engl f Med 1979;300:689-95.

2 Needleman HL, Schell A, Bellinger D, Leviton A, Allred EN. The long-term effects of exposure to low doses of lead in childhood: an 11-yea follow-up report. $N$ Engl $₹$ Med 1990;322:83-8.

3 Bellinger D, Leviton A, Waternaux C, Needleman HL, Rabinowitz M. Longitudinal analysis of prenatal and postnatal lead exposure and early cogntive development. $N$ Engl ₹ Med 1987;316:1037-43.

4 Bellinger D, Sloman J, Leviton A, Rabinowitz M, Needleman HL, Waternaux C. Low-level lead exposure and children's cognitive function in the preschool years. Pediatrics 1991;87:219-27.

5 Bellinger D, Stiles K, Needleman HL. Low-level lead exposure intelligence and academic achievement: a long-term follow-up study. Pediatric and academic $1992 ; 90: 855-61$.

6 Dietrich KN, Krafft KM, Bornschein RL, Hammond PB, Berger O Dietrich KN, Krafft KM, Bornschein RL, Hammond PB, Berger O, Succop PA, et al. Low-level fetal lead exposure effect on

7 Dietrich KN, Succop PA, Berger OG, Hammond PB, Bornschein RL. Lead exposure and the cognitive development of urban preschool children: the Cincinnati lead study cohort at age 4 years. Neurotoxicol Terato 1991;13:203-11.

8 Dietrich KN, Succop PA, Berger OG, Keith RW. Lead exposure and the central auditory processing abilities and cognitive development of urban children: The Cincinnati lead study cohort at age 5 years. Neurotoxicol Teratol 1991;13:203-11.

9 Wigg NR, Vimpani GV, McMichael AJ, Baghurst PA, Robertson EF, Roberts RI. Port Pirie cohort study: childhood blood lead and neuropsychoerts RJ. Port Pirie coh McMich: childhood blood lead and neuropsycho1988;42:213-9.

10 McMichael AJ, Baghurst PA, Wigg NR, Vimpany GV, Robertson EF, Roberts RJ. Port Pirie cohort study: Environmental exposure to lead and chilerts RJ. Port Pirie cohort study: Environmental exposure to lead and chil-

11 Baghurst PA, McMichael AJ, Wigg NR, Vimpany GV, Robertson EF, Roberts RJ, et al. Environmental exposure to lead and children's intelligence at the age of seven years: the Port Pirie cohort study. N Engl $f$ Med 1992;327:1279-84.

12 Ernhart CB, Morrow-Tlucak M, Wolf AW, Super D, Drotar D. Low level lead exposure in the prenatal and early preschool periods: intelligence prior to school entry. Neurotoxicol Teratol 1989;11:161-70.

13 Cooney GH, Bell A, McBride W, Carter C. Low-level exposure to lead: the Sydney lead study. Dev Med Child Neurol 1989;31:640-9.
14 Dietrich KN, Succop PA, Berger OG, Hammond PB, Bornschein RL. Lead exposure and the motor developmental status of urban six-year-old children in the Cincinnati prospective study. Pediatrics 1993;91:301-7.

15 Smith M, Delves T, Lansdown R, Clayton B, Graham P. The effects of lead exposure on urban children: the Institute of Child Health/Southampton study. Dev Med Child Neurol 1983;47(suppl):1-54.

16 Fulton M, Raab GM, Thomson GOB, Laxen DPH, Hunter R, Hepburn W. Influence of blood lead on the ability and attainment of children in Edinburgh. Lancet 1987;i:1221-6.

17 Needleman HL, Gatsonis CA. Low-level lead exposure and the IQ of children: a meta-analysis of modern studies. JAMA 1990;263:673-8.

18 Centers for Disease Control. Preventing lead poisoning in young children: $A$ statement by the Centers for Disease Control. Atlanta: Centers for Disease Control, 1991 .

19 Australian Commonwealth Department of Human Services and Health Reducing lead exposure in Australia: an assessment of impacts. Canberra: Australian Government Publishing Service, 1994.

20 Brody DJ, Pirkle JL, Kramer RA, Flegal KM, Matte TD, Gunter EW, et al. Blood lead levels in the US population. FAMA 1994;272:277-83.

21 Wechsler D. Manual for the Wechsler intelligence scale for children-revised. New York: Psychological Corporation USA, 1974.

22 Standards Association of Australia. Whole blood determination of lead electrothermal atomization atomic absorption spectrometric method. Sydney: Standards Association of Australia, 1985. (Australian Standard 2787.)

23 Daniel A. The measurement of social class. Community Health Studies 1984;3:218.

24 Byles J, Byrne C, Boyle MH, Offord DR. Ontario child health study: reliability and validity of the general functioning subscale of the McMaster family assessment device. Family Proc 1988;27:97-104.

25 Goldberg D. Manual of the general health questionnaire. Windsor: NFER-Nelson, 1978.

26 Caldwell B, Bradley R. Home observation for measurement of the environmen New York: Dorsey USA, 1985

27 Wechsler D. Wechsler adult intelligence scale-revised. New York: Psychological Corporation USA, 1981

28 Kleinbaum DG, Kupper LL, Morgenstern H. Epidemiological research:principles and quantitative methods. Belmont: Lifetime Learning Publications, 1982.

29 Mickey RM, Greenland $S$. The impact of confounder selection criteria on effect estimation. Am $\mathcal{F}$ Epidemiol 1989;129:125-37.

30 Fergusson DM, Horwood LJ. The effects of lead levels on the growth of word recognition in middle childhood. Int $\Im$ Epidemiol 1993;22:891-7.

31 Smith MA. The effects of low-level lead exposure on children. In: Smith M, Grant L, Sors A, eds. Lead exposure and child development: an international assessment. Lancaster: Kluwer, 1989:3-48.

32 Pocock SJ, Smith MA. Lead and children's IQ. Lancet 1987;ii:53-4.

33 Gilbert SG, Rice DC. Low-level lifetime lead exposure produces behavioral toxicity (spatial discrimination reversal) in adult monkeys. Toxicol Appl Pharmacol 1987;91:484-90.

34 Rice DC, Karpinski KF. Lifetime low-level lead exposure produces deficits in delayed alternation in adult monkeys. Neurotoxicol Teratol 1988;10:207 14.

35 Silbergeld E. Experimental studies of lead neurotoxicity: implications for mechanisms, dose-response and reversibility. In: Rutter M, Jones RR, eds. Lead versus health. Chichester: Wiley, 1983:191-216.

36 Pocock SJ, Smith $M$, Baghurst P. Environmental lead and children's intelligence: a systematic review of the epidemiological evidence. $B M$ gence: a systematic

37 US Environmental Protection Agency. Air quality criteria for lead. Research Triangle Park, NC: Office of Health and Environmental Assessment, Environmental Criteria and Assessment Office, 1986. (EPA report No EPA-600/8-83/028aF-dF.)

38 McMichael AJ, Baghurst PA, Vimpani GV, Robertson EF, Wigg NR, Tong S. Sociodemographic factors modifying the effect of environmental lead on neuropsychological development in early childhood. Neurotoxicol Teratol 1992;14:321-7.

39 Kaufman AS. Intelligent testing with the WISC-R. New York: Wiley, 1979:1-69.

40 Sattler JM. Assessment of children. San Diego: Jerome M. Sattler, 1988:61-190

41 Rius RA, Govoni S, Bergamaschi S, Lucchi L, Trabucchi M. Mechanisms of the effect of lead on brain neurotransmission: a calcium mediated action. Sci Total Environ 1988;71:441-8.

42 Goldstein GW. Neurologic concepts of lead poisoning in children. Pediatric Annals 1992;21:384-8.

43 Markovac J, Goldstein GW. Picomolar concentrations of lead stimulate brain protein kinase C. Nature 1988;334:71-3.

44 Levin ED, Bowman RE, Wegert S, Vuchetich J. Psychopharmacological investigations of a lead-induced long-term cognitive deficit in monkeys. Psychopharmacol 1987;91:334-41.

45 Ronnback L, Hansson E. Chronic encephalopathies induced by mercury or lead: aspects of underlying cellular and molecular mechanisms. Br f Indust Med 1992;49:233-40.

(Accepted 3 April 1996) 